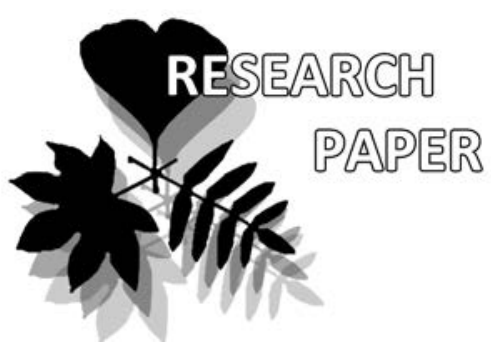

\title{
Tayloria rudolphiana in Russia, a range extension of worldwide rare moss species
}

\author{
Elena A. Ignatova ${ }^{1 *}$, Olga Yu. Pisarenko², Oxana I. Kuznetsova ${ }^{3}$ \\ \& Michael S. Ignatov ${ }^{1,3}$
}

Elena A. Ignatova ${ }^{1 *}$

e-mail: arctoa@list.ru

Olga Yu. Pisarenko²

e-mail: o_pisarenko@mail.ru

Oxana I. Kuznetsova ${ }^{3}$

e-mail: oikuznets@gmail.com

Michael S. Ignatov ${ }^{1,3}$

e-mail: misha_ignatov@list.ru

${ }^{1}$ Lomonosov Moscow State University, Faculty of Biology, Plant Ecology and Geography Department, Moscow, Russia

${ }^{2}$ Central Siberian Botanical Garden SB RAS, Novosibirsk, Russia

${ }^{3}$ Tsitsin Main Botanical Garden RAS, Moscow, Russia

* corresponding author

Manuscript received: 25.09.2021

Review completed: 25.10 .2021

Accepted for publication: 27.10.2021

Published online: 29.10.2021

\begin{abstract}
A B S T R A C T
Tayloria rudolphiana is documented in Altai Mountains, Russia as the first occurrence in North Asia. Previously this species was known in a limited range in Central Europe in Austria, Germany and Switzerland, where it at present is critically endangered to vulnerable. There are two disjunctive localities in China, a recent one in Hubei and a hundred year old collection in Yunnan. Our finding in Altai, in spruce forests in middle mountain zone in moderate abundance is important for assessment of the species conservation status. Molecular barcoding data of the plastid $r p s 4$ and $t r n \mathrm{~L}-\mathrm{F}$ sequences support the species identity.
\end{abstract}

Keywords: rare species, new record, disjunct distribution, conservation

\section{P E 3 Ю M E}

Игнатова Е.А., Писаренко О.Ю., Кузнецова О.И., Игнатов М.С. Tayloria rudolphiana, реАкий во всем мире виА, найден в России. Tayloria rudolphiana найдена в России в Горном А^тае; это первая находка вида в северной части Азии. Этот вид был ранее известен как имеющий ограниченный ареал в Центральной Европе - в Австрии, Германии и Швейцарии, где его состояние оценивается как критически угрожаемое или уязвимое. Он был также найден в двух дизъюнктивных местонахождениях в Китае: недавно в Хубее и около ста Ает назал в Юннане. Находка T. rudolphiana на А^тае, где вил был умеренно обилен в ельниках в среднем горном поясе, важна Аля оценки его охраняемого статуса. Баркодирование с помощью хлоропластных маркеров $r p s 4$ и $t r n \mathrm{~L}-\mathrm{F}$ подтвержАает приналлежность алтайских образцов к этому виАу.

КАючевые слова: редкий виА, новая находка, дизъюнктивное распространение, сохранение
There are a number of enigmatic and huge disjunctions in mosses between East Asia and Europe. Some examples are strictly confined to the Alps and then East Asia: both Distichophyllum carinatum Dixon \& W.E. Nicholson (IUCN 2012) and Ortholimnobium handelii (Broth.) Schröck \& J.T. Wynns (Wynns \& Schröck 2018) are not known elsewhere. Among other species, e.g. Orthothrichum callistomum Fisch.-Oost. ex Bruch \& Schimp. was for a long time known only in these two areas, in Asia in China (Yu et al. 2011) and Nepal (Lewinsky 1992) and in Europe in Switzerland, where it is extirpated (Lewinsky 1992). Recently O. callistomum, however, was discovered in the Caucasus (Akatova et al. 2004) and in Turkey (Lara et al. 2010). Another example is Ulota rehmanii Jur., described from Tatra Mts in Poland and known from few localities in Central European countries (Hodgetts \& Locart 2020), whereas it turned to be widespread in Altai (Ignatov \& Ochyra 1994), southern Siberia, and Russian Far East (Fedosov \& Doroshina 2018).

Tayloria rudolphiana (Garov.) Bruch \& Schimp. comprises a similar case. This species was described from Germany and has a very limited range in Central Europe. Hodgetts \& Locart (2020) reported it as critically endangered in Austria, endangered in Germany and vulnerable in Switzerland three countries where it occurs in Europe. Koponen (1992) found that T. delavayi (Besch.) Besch. described from Yun- nan Province of SW China is identical with European T. rudolphiana. These specimens from Yunnan remained for more than a hundred years as the only collections of $T$. rudolphiana from China. Fortunately, quite recently, Yi et al. (2020) rediscovered this species in Hubei Province, China. These authors also provided a comprehensive comparison of European and Chinese plants, assuring in their identity both in morphology and DNA sequences.

During the field trip in Altai in 2021 we also collected this species. For additional certainty, its DNA has been studied as well.

\section{STUDY AREA}

In Altai Republic, Tayloria rudolphiana was collected on right side of the Chuya River valley between the mouths of tributaries Yarbalyk and Boka (Fig. 1).

Chuya valley is sublatitudinally stretched. Altitudes vary from $1000 \mathrm{~m}$ a.s.l. at the river level to $2500 \mathrm{~m}$ at the tops of adjacent ridges. The site is located in the area of the ancient second Late Pleistocene (Sartan) glaciation (Zarutskaya 1978). In the scheme of climatic zoning it is situated on the border of the semigumid and semiarid bioclimatic sectors (Polikarpov et al. 1986, Makunina 2016).

The climate is sharply continental. The climatic conditions in the valley differ significantly from those on the adja- 
cent ridges: precipitation is reduced in the valley, the average dryness of the air is higher, average daily and summer temperatures are increased, and at the same time cold air stagnates here in winter; there is a temperature inversion. The climatic conditions in the Chuya valley in the middle reaches are similar to those in the Chuya Steppe. The sum of temperatures above $10^{\circ} \mathrm{C}$ roughly is $1200^{\circ}$. The average annual precipitation is about $300 \mathrm{~mm}$, and around $80 \%$ of it falls in the period from April to October; winter is snowless (Zarutskaya 1978).

The vegetation of the territory is a combination of true steppes and meadow-steppes on river terraces and southern slopes with cryophytic larch ("pseudo-taiga") forests on the slopes of shadow expositions (Ermakov 2003, Makunina 2016). The highlight of the vegetation cover on the segment of the Chuya valley are peculiar spruce (Picea obovata Ledeb.) forests.

On the spot, the Picea-forests exist in the form of small islands on the river terrace and at the foot of the steep southern slope on a large-block scree (Fig. 2).

Tree canopy is rather open, the projective cover is about 50-60\%; Picea trees are old-age, about $40 \mathrm{~cm}$ in diameter and about $20 \mathrm{~m}$ high. Under the canopy Caragana arborescens Lam. is abundant. Herb layer is scattered; separate scattered shoots and curtains rise above the closed moss carpet, the most abundant are Brachypodium pinnatum (L.) P. Beauv., Schizachne callosa (Turcz. ex Griseb.) Ohwi, Carex alba Scop. From mosses Rhytidium rugosum (Hedw.) Kindb. and Abietinella abietina (Hedw.) M. Fleisch. prevail on forest litter; Entodon schleicheri (Bruch, Schimp. \& W. Gümbel) Demet., Rhodobryum ontariense (Kindb.) Kindb. are abundant. Large boulders of shale up to 2-3 $\mathrm{m}$ in size are overall; they are covered by Leucodon sciuroides (Hedw.) Schwägr., Tortella fragilis (Hook.\& Wilson) Limpr., T. tortuosa (Hedw.) Limpr., Hedwigia emodica Hampe ex Müll. Hal., H. mollis Ignatova, Ignatov \& Fedosov, Hymenoloma crispulum (Hedw.) Ochyra, Grimmia longirostris Hook., Schistidium pulchrum H.H. Blom.,

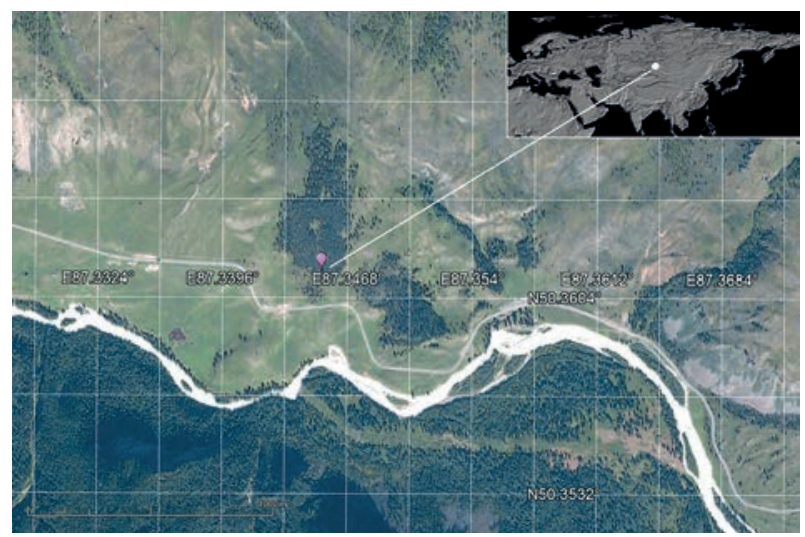

Figure $1 \mathrm{~A}$ fragment of Quick Bird space image of the surveyed area. The light strip is the Chuya riverbed. The difference in the predominant vegetation of the northern and southern slopes of the river valley is visible. The slope of the northern exposure (lower part of the image) is forested; that are larch forests. The slope of the southern exposure (upper part of the image) is mostly treeless; these are various steppe communities; scattered trees in the upper part of the image are also larches; but dense forest "islands" in the lower part of the slope are formed by Picea obovata. Tayloria locality is marked.
Dicranum dispersum Engelmark, Bryum capillare Hedw., Trachycystis ussuriensis (Maack \& Regel) T.J. Kop., Bryoerythrophyllum recurvirostrum (Hedw.) P.C. Chen, Fabronia ciliaris (Brid.) Brid., Struckia enervis (Broth.) Ignatov, T.J. Kop.\& D.G. Long, Leptopterigynandrum incurvatum Broth., etc.

In general, spruce forests are rare in Altai. They occupy small areas and are associated with plots with excessive moisture and low soil temperature. Such places are the bottoms of narrow and deep valleys, where the cold air rolls down from the mountains and stagnates, aufeis and seasonal soil permafrost often form here; valleys of cold streams, places of an outlet of cold springs, etc. are also similar (Kuminova 1960). In our case, the existence of the Picea forests is caused probably by the presence of permafrost in the body of large-block scree at the foot of the slope. Such environment maintains high moisture by permanent seepage from melting permafrost, cold temperature of stone, which act as air moisture condensers at nights, and dense canopy of Picea trees that precludes over-drying in daytime. This specific and long-existing conditions form refugia of a high conservation value.

For similar spruce forests growing at the same latitude and also in a forest-steppe environment of the Academician Obruchev Range (Republic of Tuva), it was shown that the specificity of their species composition is not derived from the current situation and can only be explained by the relict nature of these communities, their formation in the conditions of the Late Pleistocene periglacial climate on permafrost soils (Laschinsky \& Pisarenko 2021).

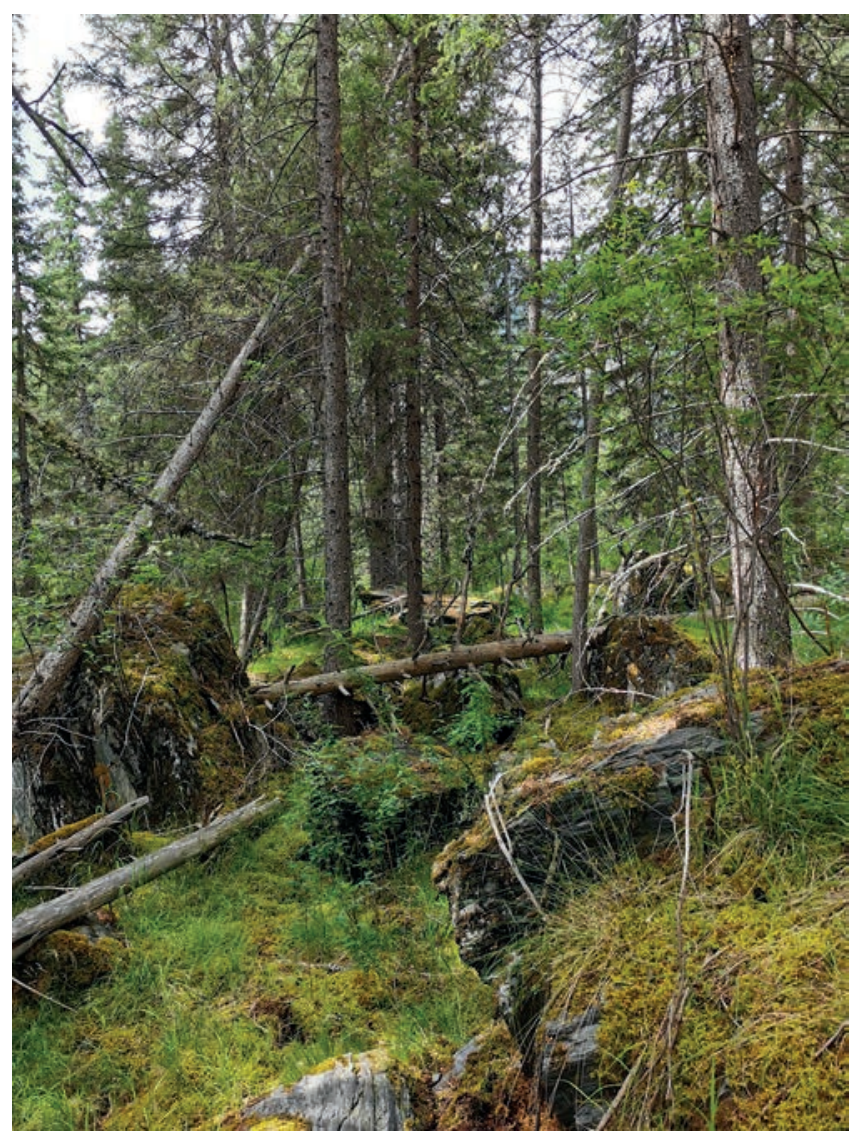

Figure 2 Spruce forest with rock outcrops where Tayloria rudolphiana (Garov.) Bruch \& Schimp. has been collected. Foto by Olga Pisarenko 


\section{MATERIAL AND METHODS}

Sequence acquiring. The laboratory protocol and sequencing was essentially the same as in our previous moss studies, described in detail by, e.g., Gardiner et al. (2005). Plastid regions were amplified for rps 4 with forward RPS5 primer (ATG TCC CGT TAT CGA GGA CCT) and reverse TRNAS (TAC CGA GGG TTC GAA TC) (Nadot et al. 1995) an for trn L-trnF with forward TRNC (CGA AAT CGG TAG ACG CTA CG) and reverse TRNF (AT'T TGA ACT GGT GAC ACG AG) (Taberlet et al. 1991).

The dasaset was build by sequences found to be maximally similar by BLAST among GeneBank collections.

One collection of Tayloria acuminata Hornsch. from the same as our Altai trip was also added to the studied set.

Sequences were aligned in Bioedit (Hall 1999).

Molecular phylogenetic analysis was conducted in MrBayes 3.2.6 (Ronquist et al. 2012), with two compartments for rps4 DNA: coding region with the HKY+I model, $595 \mathrm{bp}$, and the rps 4 spacer with the HKY model, $41 \mathrm{bp}$. One compartment for the $t r n \mathrm{~L}-\mathrm{F}$ region, $443 \mathrm{bp}$ $(\mathrm{GRT}+\mathrm{I})$. Convergence of each analysis was evaluated using Tracer1.4.1 (Rambaut \& Drummond 2007). Consensus trees were calculated after omitting the first $25 \%$ trees as burn-in. Maximum parsimony analysis was performed in Nona (Goloboff 1994) in the Winclada shell (Nixon 1999), with bootstrap calculations for 2000 replications (N searches 100, starting trees per rep 100, max trees 100, do max). As accession for two studied regions were not the same, the phylogenetic analysis was conducted to two regions separately.

\section{RESULTS AND DISCUSSION}

The analysis of both plastid regions confirms the identity of Altaian specimens of T. rudolphiana with European plants. Unfortunately Chinese sequences were not available in GenBank (20 October 2021). Both Bayesian posterior probabilities and maximum parsimony bootstrap showed maximal support (Figs 3-4).

Our collections from Chuya River Valley in Altai Republic agree in all essential morphological characters with the detailed description of Tayloria rudolphiana provided by Yi et al. (2020), as well as with illustrations of European and Chinese (Yunnan) plants given in Koponen (1992) and of collection from Bavaria in Lüth (2019). The only difference of plants from Altai worth mentioning is the smaller size of leaves: $3.23-3.75 \times 0.8-1.1 \mathrm{~mm}$ vs. $4-5.5 \times 1-1.5 \mathrm{~mm}$ in plants from Hubei (Yi et al. 2020). Illustrations in Koponen (1992) show leaves 4.0-4.5 × 1.0-1.6 $\mathrm{mm}$ for European plants and 3.1-6.0 × 1.0-2.4 mm for plants from Yunnan. Photo in Lüth (2019) illustrates one leaf $4.6 \times 1.6 \mathrm{~mm}$. However, plants from Switzerland (E. Bauer, Musci europaei exsiccati \#847, MW9023640) have leaves similar in size to those in collections from Altai Mts., i.e. $2.8-3.75 \times 1.0-1.5 \mathrm{~mm}$. Thus, based both on molecular and morphological data, we refer the collections from Altai to T. rudolphiana.

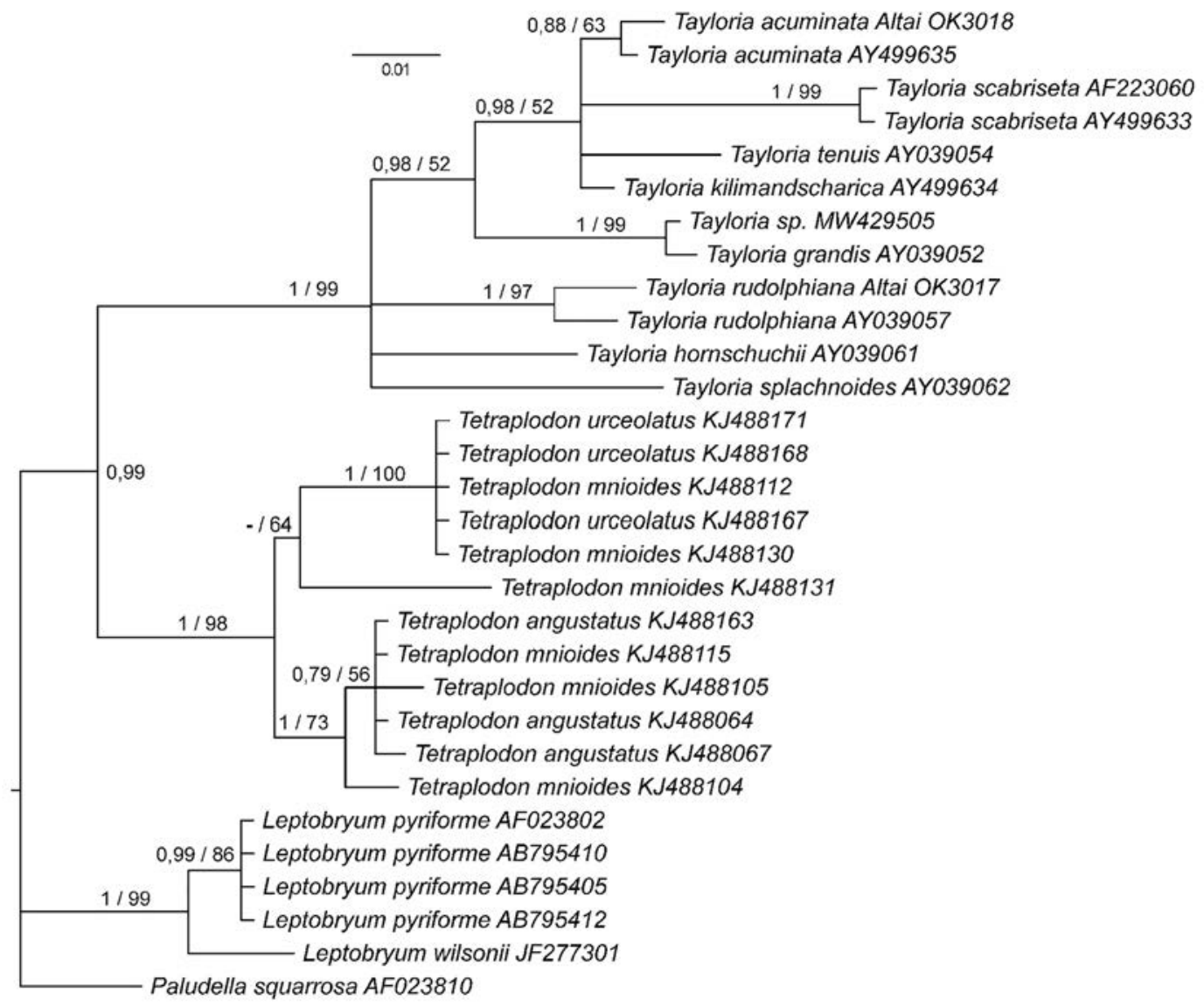

Figure 3 Bayesian tree confirming identity of Altaian Tayloria rudolphiana (Garov.) Bruch \& Schimp. inferred from the plastid $\operatorname{trn} \mathrm{L}-\mathrm{F}$ analysis. Bayesian posterior probabilities and / MP bootstrap supports are shown at branches. New sequences: T. acuminata OK3018: Ignatov \& Ignatova 21-176 MHA: OK662461; T. rudolphiana OK3017: Ignatova 21-787 MHA: OK662460. 


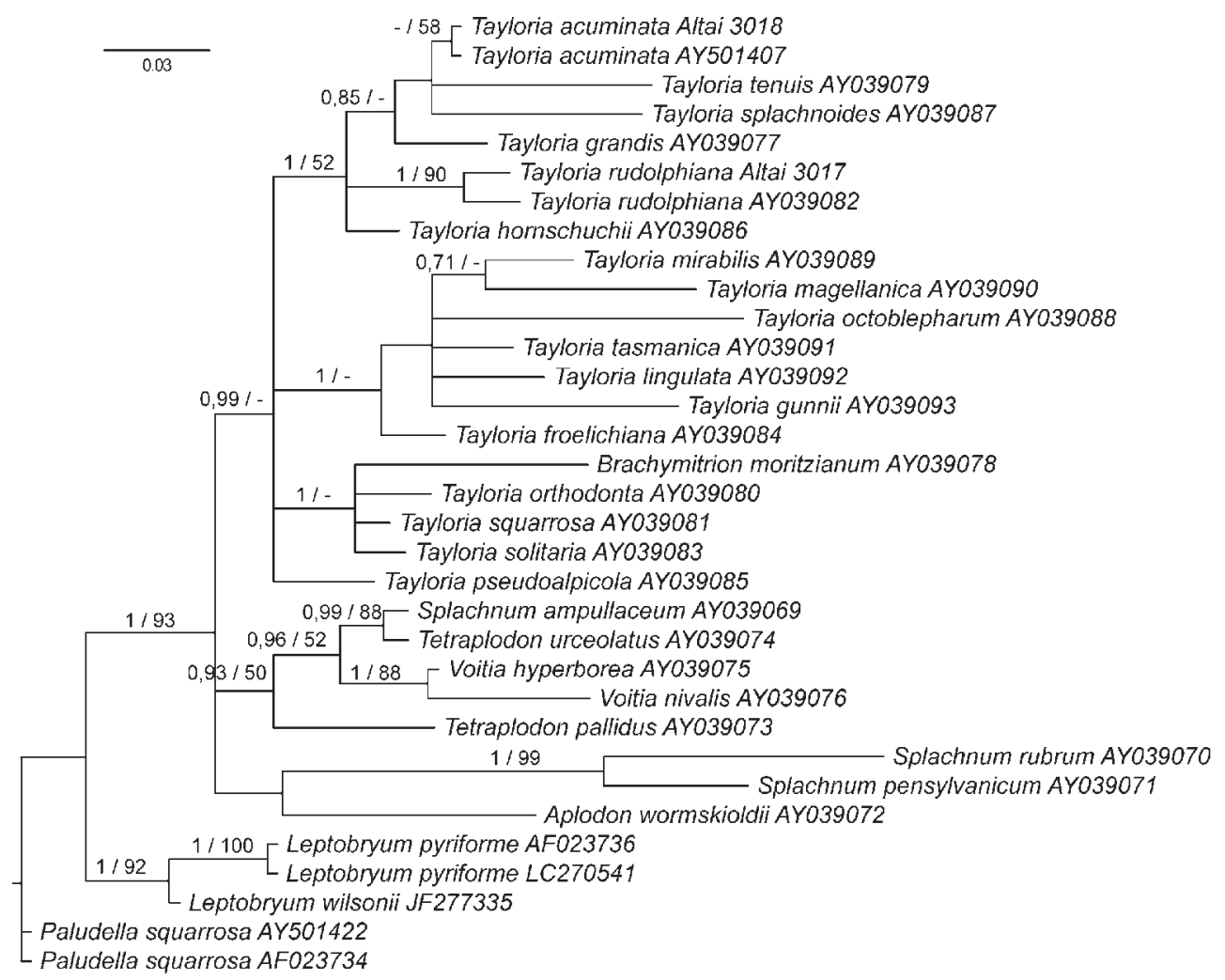

Figure 4 Bayesian tree confirming identity of Altaian Tayloria rudolphiana (Garov.) Bruch \& Schimp. inferred from the plastid $r p s 4$ analysis. Bayesian posterior probabilities and / MP bootstrap supports are shown at branches. New sequences: T. acuminata OK3018: Ignatov \& Ignatova 21-176 MHA: OK662463; T. rudolpbiana OK3017: Ignatova 21-787 MHA: OK662462

In Altai T. rudolphiana was collected on rocks (vertical walls and small ledges) covered by mixed moss tufts. It is similar to habitat of this species in Hubei described by $\mathrm{Yi}$ et al. (2020), but differs from its habitats in Yunnan and Europe, were it always grows on trunks of deciduous trees (maples in Europe and oaks in Yunnan) (Koponen 1992). However, such shift in habitat preferences is common in mainly epiphytic mosses, e.g. Leucodon sciuroides (Hedw.) Schwägr., Anomodon viticulosus (Hedw.) Hook. \& Taylor, Pseudanomodon attenuatus (Hedw.) Ignatov \& Fedosov, Leptodon smithii (Dicks. ex Hedw.) F. Weber \& D. Mohr, etc.
Below we provide the description of $T$. rudolphiana based on collections from Altai Republic.

Tayloria rudolphiana (Garov.) Bruch \& Schimp., Bryol. Eur. 3: 208. pl. 287 (fasc. 23-24, Monogr. 10. pl. 4). 1845. - Splachnum rudolphianum Garov., Bryol. Austr. Excurs. 22. 1840. - Tayloria delavayi (Besch.) Besch., Ann. Sci. Nat., Bot., ser. 7, 15: 59. 1892. - Orthodon delavayi Besch., Rev. Bryol. 18: 88. 1891. Figs 5C, 6.

Protologue: [Austria, Salzburg]: "Auch auf dem Radstatter-Tauern, etwa eine Viertel Stunde über dem St. JohannWasserfall auf Baümen die beim Aufwärtssteigen an der
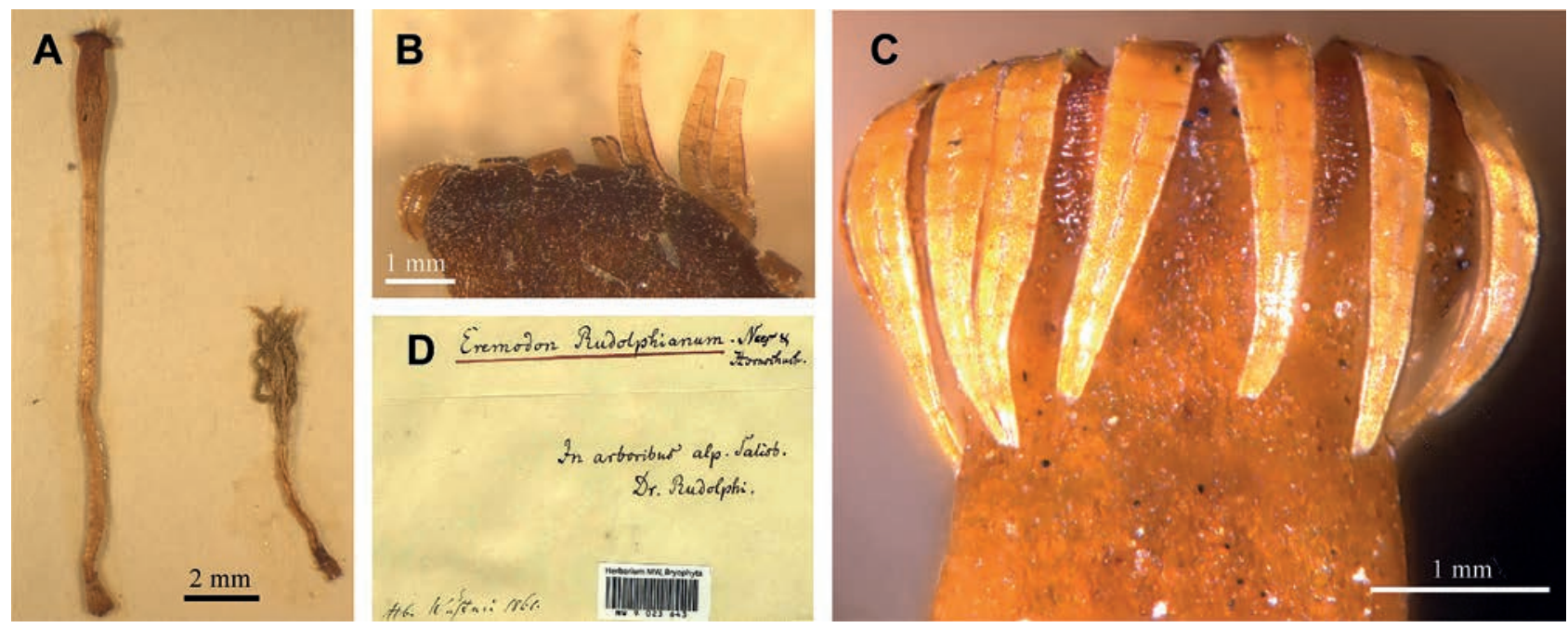

Figure 5 Tayloria rudolphiana (Garov.) Bruch \& Schimp., A-B \& D: putative isotype, including whole specimen (A), peristome, partly broken (B), and its label (D); C: peristome of Altaian plant (from Ignatova 21-787). 


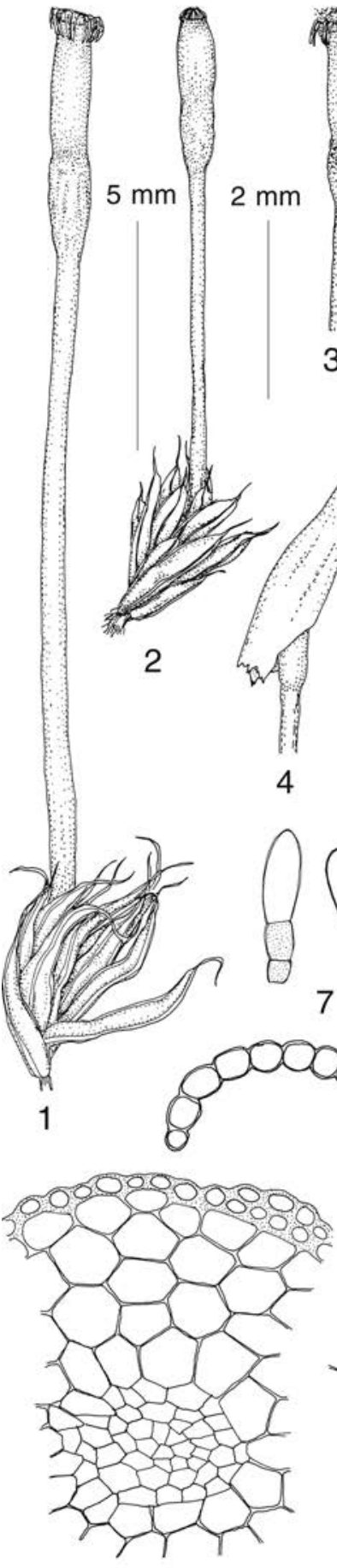

14
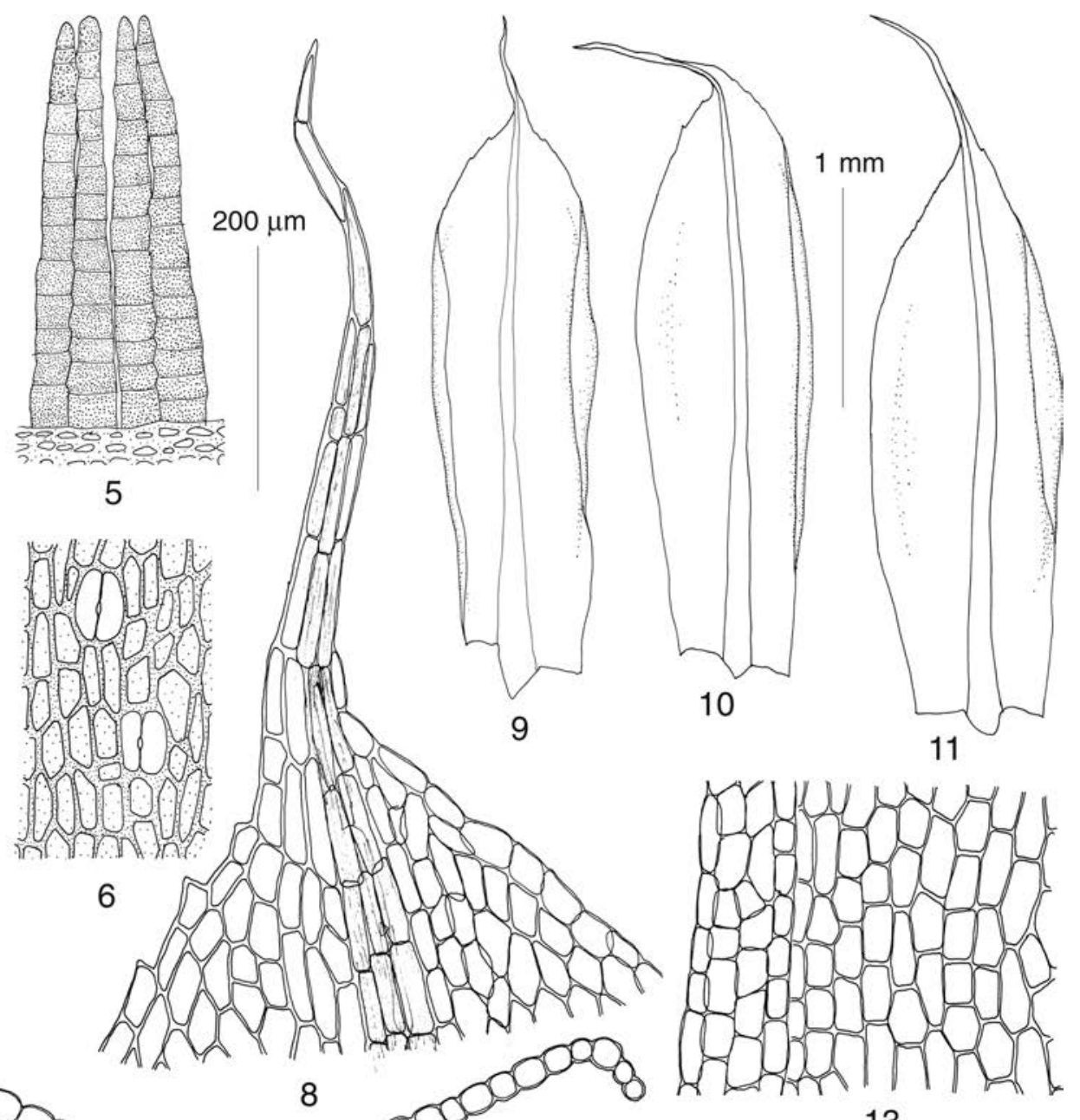

13

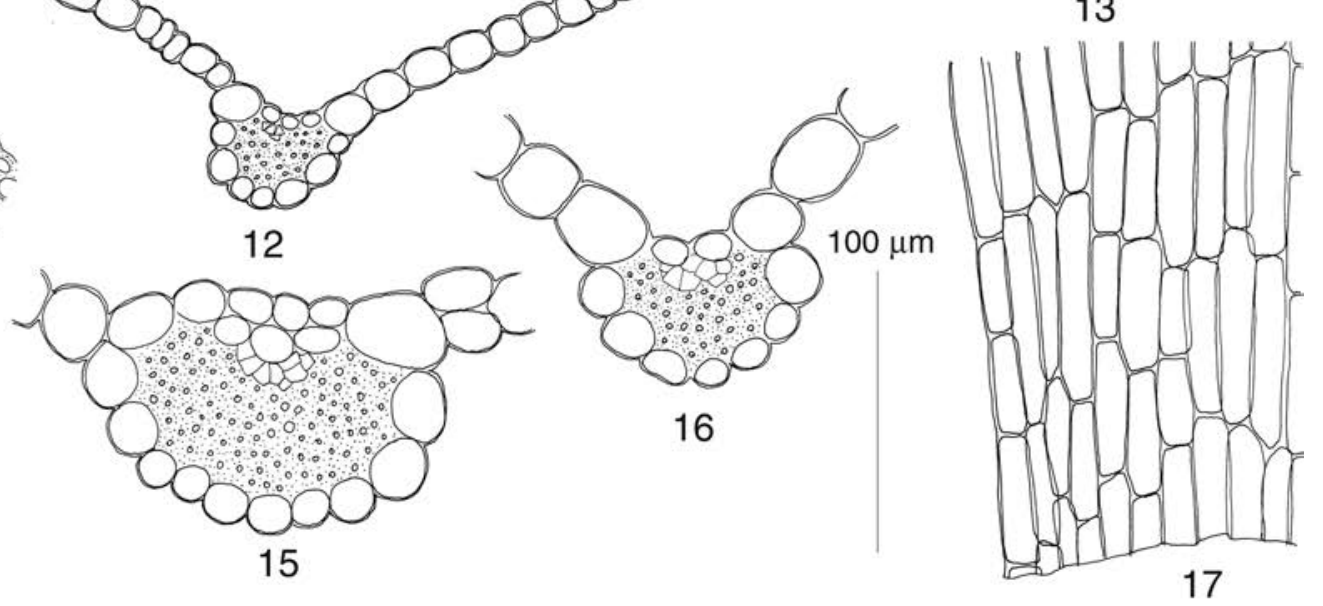

Figure 6 Tayloria rudolphiana (Garov.) Bruch \& Schimp. (from: Russia, Altai Republic, Ignatova 21-787). 1: habit, dry; 2: habit, wet; 3: capsule; 4: calyptra; 5: part of peristome; 6: exothecium cells and stomata; 7: axillary hairs; d: upper leaf cells; 9-11: leaves; 12, 15-16: leaf transverse sections; 13: median leaf cells; 14: stem transverse section; 17: basal leaf cells. Scale bars: $5 \mathrm{~mm}$ for 2; $2 \mathrm{~mm}$ for 1, 3-4; $1 \mathrm{vv}$ for 9-11; 200 $\mu \mathrm{m}$ for $5-6,8,12-13,17 ; 100 \mu \mathrm{m}$ for $7,14-16$.

rechten Seite des Weges an schroffen Abhängen stehen, und zwar auf den etwa 20-25' von Boden entfernten dickeren Aesten, in grossen, lockeren Rasen zwischen andern Moosen z.B. Leucodon sciuroides. Hr. Rudoiphi, September 1826".

According to Bruch et al. (1844), Rudolphi collected this species in only one place. Therefore a small duplicate of the collection of Rudolphi in MW is a putative isotype
(Fig. 5 A-B, D). A note on the envelope "Hb. Wustnei, 1861" likely means that the specimen was from the herbarium of Karl Georg Gustav Wüstnei (1810-1858), that after his death had been partly acquired by Moscow University. The specimen includes one gametophyte with leaves with obviously excurrent costa and one sporophyte with partly broken teeth, robust stature of which is similar to that in recently collected specimens with well preserved teeth (Fig. 5 D). 
Description. Plants medium-sized, ca. $2 \mathrm{~cm}$ high (with sporophytes), green to yellowish-green above, brownish below, dull, in loose tufts or growing as an admixture among other mosses. Stems erect or ascending, simple, ca. $0.5 \mathrm{~cm}$ long, with dense rhizoids below, in transverse section with 1-2-layered sclerodermis, 4-6 layers of thin-walled medullar cells and large, well-differentiated central strand. Leaves contorted when dry, erect when moist, oblong ovate or oblong-obovate, attenuate at apex, 3.23-3.75(5.5) $\times$ 0.8-1.1(1.5) mm; costa strong, $130-150 \mu \mathrm{m}$ wide at base, gradually narrowing distally, excurrent, filling upper portion of attenuate apiculus $0.4-0.8 \mathrm{~mm}$ long, in transverse section with 1-2 rows of ventrally exposed guide cells, hydroid strand, large stereid band and well differentiated dorsal epidermis formed of large cells; margins irregularly serrate below apiculus, entire at the rest length below, widely recurved almost throughout except distalmost portion on one side and in midleaf on the other side or occasionally plane; upper leaf cells elongate-hexagonal, 30-70 × 20-25 $\mu \mathrm{m}$; basal leaf cells elongate-rectangular, 65-140 × 20-25 $\mu \mathrm{m}$, all cells thin-walled, not porose. Axillary hairs 3-celled, with large, inflated, hyaline upper cell and two smaller, light brownish basal cells. Autoicous, sporophytes frequent. Perichaetial leaves similar to stem leaves. Setae to $2.2 \mathrm{~cm}$ long, thick, light brownish. Capsules long cylindrical, to $5 \mathrm{~mm}$ long, brown, gradually tapered to seta, constricted below mouth, apophysis weakly differentiated; opercula conic; annuli weakly differentiated, persistent; peristome single, consisting of 16 teeth ca. $350 \mu \mathrm{m}$ long, reflexed when dry and appressed to capsule wall, erect when moist, finely papillose on dorsal surface; stomata present in apophysis, numerous, superficial. Spores 9-10 $\mu \mathrm{m}$. Calyptra cucullate, lobed at base.

Differentiation. Among seven species of Tayloria which were already known in Russia, T. acuminata is most similar to T. rudolphiana in having leaves with attenuate apices, long-cylindrical capsules, and reflexed in dry state peristome teeth. However, T. rudolphiana differs from that species in (1) having excurrent costa vs. ending at base of apiculus; (2) widely recurved vs. plane leaf margins, which are dentate only in distalmost portion vs. at ca. 1/3-1/2 of upper leaf portion; (3) less strongly curved peristome teeth in dry state; and (4) smaller spores, 9-10 $\mu \mathrm{m}$ vs. 14-22 $\mu \mathrm{m}$.

Specimens examined: Russia, the Altai Republic, Ongudai District: valley of Chuya River between Chibit and Yarbalyk settlements, right slope, 50²1'41"N 87²0'48"E, 1100 m a.s.l., 24 June 2021, Ignatova 21-787 (MHA9135058), 21-619 (MHA9131135, MW9092184) and 21-606 (MHA9131144, MW9092189); right side of the Chuya River valley between the mouths of tributaries Yarbalyk and Boka, 50.36133ㅇN 87.34532 E, 1100 m a.s.l., 24 June 2021, Pisarenko s.n. (NSK2009234, NSK2009235).

\section{ACKNOWLEDGEMENTS}

We are grateful to James Shevock for correcting English of the manuscript. The molecular study was supported by RSF 18-14-00121. Samples in NSK are located in biocollection USU 440537. We also acknowledge Ministry of Higher Education and Science of Russian Federation for the support the Center of Collective Use "Herbarium MBG RAS”, grant 075-15-2021-678.

\section{LITERATURE CITED}

Akatova, T.V., Z.K. Kharzinov, E.A. Ignatova \& M.S. Ignatov 2004. On three rare species of Orthotrichum (Orthotrichaceae, Musci) in the Caucasus. Arctoa 13:41-49.

Bruch, P. \& W.P. Schimper 1844. Fasciculus 23-24. Oedipodium, Tayloria, Dissodon, Tetraplodon, Splachnum, Orthodontium, Mielichhoferia. In: Bryologia Europaea, E. Schweizerbart, Stuttgart.

Ermakov, N.B. 2003. Diversity of boreal vegetation of Northern Asia. Hemiboreal forests. Classification and ordination. Izdatel'stvo Sibirskogo otdeleniya Rossiyskoy akademii nauk, Novosibirsk, 232 pp. (in Russian). [Ермаков. Н.Б. 2003. Разнообразие бореальной растительности Северной Азии. Гемибореальные меса. Классификация и орАинация. ИзАательство Сибирского отАеления Российской Академии наук. 232 с.].

Fedosov, V.E. \& G.Ya. Doroshina 2018. Orthotrichales. In: Moss flora of Russia, vol. 4. Bartramiales - Aulacomniales (M.S. Ignatov, ed.). Arctoa 27(suppl. 1):67-195.

Gardiner, A., M. Ignatov, S. Huttunen \& A. Troitsky 2005. On resurrection of the families Pseudoleskeaceae Schimp. and Pylaisiaceae Schimp. (Musci, Hypnales). Taxon 54:651-663.

Goloboff, P.A. 1994. NONA: A Tree Searching Program. Tucumán, Argentina: Program and documentation, published by the author.

Hall, T.A. 1999. BioEdit: A User-friendly biological sequence alignment editor and analysis program for Windows 95/98/ NT. Nucleic Acids Symposium Series 41:95-8.

Hodgetts, N.G. \& N. Lockhart 2020. Checklist and country status of European bryophytes - update 2020. Irish Wildlife Manuals 123:[i-iv]i, 1-214.

Ignatov, M.S. \& R. Ochyra 1994. Bryophytes of the Altai Mountains. III. The genus Ulota (Orthotrichaceae, Musci). Arctoa 3:59-66.

IUCN SSC Bryophyte Specialist Group 2012. "Distichophyllum carinatum". IUCN Red List of Threatened Species. 2012: e.T39245A2896138. doi:10.2305/IUCN.UK.2012-1. RLTS.T39245A2896138.en. Retrieved 4 May 2020

Koponen, A.K. 1992. European-Asiatic connections in Tayloria (Splachnaceae, Musci). Bryobrothera 1:57-62.

Kuminova, A.V. I960. Vegetation cover of Altai. Izdatel'stvo Sibirskogo otdeleniya Akademii nauk SSSR, Novosibirsk, 449 pp. (in Russian). [Куминова. А.В. I960. Растительный покров Алтая. Новосибирск: ИзАательство Сибирского отделения Академии наук СССР. 449 с.].

Lara, F., V. Mazimpaka, R. Medina, R. Caparrós Callejo \& R. Garilleti 2010. Northeastern Turkey, an unnoticed but very important area for the Orthotrichaceae (Bryophyta). Nova Hedwigia Beiheft 138:165-180.

Lashchinskiy, N.N. \& O.Yu. Pisarenko 2021. Spruce forests of the Koptu River valley (the Republic of Tuva) are relict of Late Pleistocene vegetation. Vestnik Tomskogo gosudarstvennogo universiteta. Biologiya 54:45-63 (in Russian with English summary). [Аащинский Н.Н., Писаренко О.Ю. 2021. Еловые меса Аолины р. Копту (Респубмика Тыва) - реликт растительности позднего плейстоцена // Вестник Томского государственного университета. Биология. № 54. С. 45-63].

Lewinsky, J. 1992. The genus Orthotrichum Hedw. (Orthotrichaceae, Musci) in Southeast Asia. A taxonomic revision. Journal of the Hattori Botanical Laboratory 72:1-88. 
Lüth, M. 2019. Mosses of Europe. A Photographic Flora, vol. 2: 329-840. Popper and Ortman, Freiburg, Germany.

Makunina, N.I. 2016. The forest-steppe vegetation of the west Siberian plain and the Altai-Sayan mountain region. Akademicheskoe izdatel'stvo «GEO», Novosibirsk, 183 pp. [Макунина Н.И. 2016. Растительность месостепи Западно-Сибирской равнины и А^тае-Саянской горной области. Новосибирск: Академическое изА-во «Гео», 183 с.].

Maskaev, Yu.M. 1985. Forests. In: Vegetation cover and natural forage lands of the Tuva ASSR (I.Yu. Koropachinskiy, ed.), pp. 68-106, Nauka, Novosibirsk (in Russian). [Маскаев Ю.М. Аеса / / Растительный покров и естественные кормовые угодья Тувинской АССР / под реА. И.Ю. Коропачинского. Новосибирск: Наука, 1985. С. 68-106].

Nadot, S., R. Bajon \& B. Lejeune 1994. The chloroplast gene rps4 as a tool for the study of Poaceae phylogeny. Plant Systematics and Evolution 191:27-38.

Nixon, K.C. 1999. Winclada (BETA) ver. 0.9.9. Available at: http:// www.cladistics.com/about_winc.html

Polikarpov, N.P., N.M. Chebakova \& D.I. Nazimova 1986. Climate and mountain forests of Southern Siberia. Nauka, Novosibirsk, 226 pp. (in Russian). [Поликарпов Н.П., Чебакова Н.М., Назимова А.И. 1986. Климат и горные меса Южной Сибири. Новосибирск: Наука. 226 с.].

Rambaut, A. \& A.J. Drummond. 2007. Tracer v1.4. Available from http:/ / beast.bio.ed.ac.uk/Tracer.
Ronquist, F, M. Teslenko, P. Mark, Van der, D.L. Ayres, A. Darling, S. Höhna, B. Larget, L. Liu, M.A. Suchard \& J.P. Huelsenbeck 2012. MrBayes 3.2: efficient Bayesian phylogenetic inference and model choice across a large model space. Systematic Biology 61:539-542.

Taberlet, P., L. Gielly, G. Pautou \& J. Bouvet 1991. Universal primers for the amplification of three non-coding regions of chloroplast DNA. Plant Molecular Biology 17:1105-1109.

Wynns, J. T. \& C. Schröck 2018. Range extensions for the rare moss Plagiothecium handelii, and its transfer to the resurrected genus Ortholimnobium. Lindbergia 41(1):01087 [1-7].

Yi, Y.-J., X.-X. Xiao, X.-X. Xu \& S. He 2020. Revisit of European-Asiatic connections in Tayloria rudolphiana (Splachnaceae, Bryophyta) based on molecular data and new morphological evidence. Phytotaxa 438(4):247-255.

Yu, J., S. He \& S.-1. Guo 2011. Orthotrichaceae. In: Moss Flora of China, English version, vol. 5, (Wu, P.-C., M.R Crosby \& Si, H., eds), pp. 22-117, Science Press (Beijing, New York) \& Missouri Botanical Garden Press (St. Louis).

Zarutskaya, I.P. (ed.) 1978. Altai Territory. Atlas. Vol. 1. Glavnoe upravlenie geodezii i kartografii pri sovete ministrov SSSR, Moscow-Barnaul, 222 pp. (in Russian). [А^тайский край. Атлас / поА реА. И.П. Заруцкой. Москва; Барнаул: ГАавное управление геодезии и картографии при совете министров СССР. 1978. Т. 1. 222 c]. 